\title{
Heavy Metal Enrichment of Soil Irrigated with Paper and Board Mill (PBM) Effluents
}

\author{
Umer Younas $^{1}$, Shahid Iqbal ${ }^{2 *}$, Zohaib Saeed ${ }^{3}$, Saba Ibrahim ${ }^{3}$, Shazia Khurshid ${ }^{3}$, \\ Muhammad Pervaiz $^{1,3}$, Asif Saleem ${ }^{4}$, Asma Zaidi ${ }^{5}$, Munawar Iqbal ${ }^{1}$, Arif Nazir $^{1 * *}$ \\ ${ }^{1}$ Department of Chemistry, The University of Lahore, Lahore, Pakistan \\ ${ }^{2}$ Department of Chemistry, University of Sargodha, Sargodha, Pakistan \\ ${ }^{3}$ Department of Chemistry, Government College University, Lahore, Pakistan \\ ${ }^{4}$ Department of Botany, Kallar Kahar Science College, Kallar Kahar, Pakistan \\ ${ }^{5}$ Department of Chemistry, COMSATS University Islamabad, Abbottabad Campus, Pakistan
}

Received: 10 October 2019

Accepted: 29 January 2020

\begin{abstract}
The usage of industrial effluents for agricultural purposes has become common practice both in developing and developed countries. Industrial effluents may add significant amount of nutrients for the nourishment of soil. However, the presence of various pollutants in effluents may deteriorate physicochemical nature of soil. The current study presents the effect of different proportions $(0,20$, 40, 60, 80 and 100\%) of PBM effluents containing heavy metals on physicochemical properties of soil. These soil samples were analyzed at regular intervals of 30,60 and 90 days. The findings of the study indicate that lower proportions (20 and 40\%) of PBM effluents may be preferred for long- term irrigation. On the other hand, higher proportions (60,80 and 100\%) of PBM effluents may cause adverse effects on physicochemical characteristics of soil within short duration of irrigation.
\end{abstract}

Keywords: effluent reuse, irrigation, heavy metals, organic matter, enrichment

\section{Introduction}

The growing needs of increasing world population are heading towards massive industrialization and urbanization may led to environmental contamination [1, 2]. Paper and board products have become indispensable items for routine life and worldwide annual consumption of paper is now up to 300 million tons [3]. Industrial manufacturing of paper and related goods may involve various processes including digestion, pulping,

*e-mail: anmalik77@gmail.com

**e-mail: ranashahid313@gmail.com washing, bleaching and drying of raw fibrous material [4]. During all these steps, substantial amount of several chemicals and reagents are used followed by washing with huge volume of water [5] and consequently, about 455 liters effluent is being discharged for the production of one $\mathrm{kg}$ paper. The treatment of PBM effluent is expensive process. Therefore, untreated or partially treated PBM effluent is discharged into water bodies [6-8]. Deficiency of good quality irrigation water and safer disposal of effluent is considered two major factors for usage of industrial effluent in agriculture [9-11]. Additionally, effluent may introduce sufficient amount of many essential nutrients in soil for the better growth of crops. Therefore, the irrigation of agricultural 
land with wastewater is becoming a regular exercise and about 20 million hectares is being irrigated with industrial effluent [12-14]. In Pakistan, about $26 \%$ of the total vegetable crops are being irrigated with sewage or industrial wastewater [15]. In corollary, high electrical conductivity, salinity, total dissolved salts and low $\mathrm{pH}$ of effluents may introduce toxicity in soil [10, 16-23] that may decrease the plant growth. Supplementation of soil with industrial effluent can only be accepted if toxicity do not propagate in soil [24]. The impacts of various industrial effluents on physicochemical characteristics of soil depend directly or indirectly soil type, climatic conditions and constituents of industrial effluent [25]. Therefore, in order to avoid risks and to secure maximum benefits from effluents, the concentration of effluent and duration of irrigation are of fundamental importance.

The main objective of the study was to identify and endorse the advantages and disadvantages associated with the use of PBM effluents for irrigation. For the purpose, soil samples treated with different proportions of PBM effluents containing heavy metals were analyzed for physicochemical parameters at regular intervals of 30, 60 and 90 days.

\section{Material and Methods}

Effluent samples were collected in polythene bottles from diamond PBM. Soil samples were taken in 18 bowls ( $1 \mathrm{~kg}$ each) and classified into six groups ( 3 bowls each) followed by irrigation with 0 (distilled water), 20, 40, 60, 80 and 100\% PBM effluent as per irrigation requirement i.e. $80 \mathrm{~m}^{3} \mathrm{~h}^{-1}$ or to maintain $30 \%$ moisture requirement. The soil samples were dried in oven at $70{ }^{\circ} \mathrm{C}$ for 2 days and ground to pass through $2 \mathrm{~mm}$ sieve. Physicochemical properties of soil samples were analyzed in terms of $\mathrm{pH}$, electrical conductivity (EC), OM, available phosphorous, potassium, nitrogen, soil texture and metal contents. The $\mathrm{EC}$ and $\mathrm{pH}$ of the soil samples was measured using $\mathrm{pH}$ meter (Jenway 3505, UK) and conductivity meter (Inolab, Germany) respectively. $\mathrm{OM}$ in soil samples was calculated following titrimetric method [26]. Kjeldahl method was employed for the determination of nitrogen percentage. Available phosphorus and potassium in all the samples of soil was determined following colorimeter method [27]. Moisture content was determined to calculate water holding capacity of soil samples. The percentage of sand, silt and clay was calculated using Bouyoucos hydrometer (Fisher brand Model \# 14-331-5c) and already reported mathematical model [28]. Digestion of soil samples was performed using concentrated $\mathrm{HF}, \mathrm{HClO}_{4}$ and $\mathrm{HNO}_{3}$ (1:1:5) for $1 \mathrm{~g}$ soil sample. After digestion, the samples were filtered and diluted with deionized water up to constant volume [29]. The concentration of heavy metals was determined by atomic absorption spectrometer (Perkin Elmer; Pinnacle ${ }^{\mathrm{TM}}$ 900H) using air-acetylene flame for combustion with single-element hollow cathode lamp. The extent of metal accumulation in soil upon irrigation with PBM effluent was assessed by calculating enrichment factor i.e. the amount of metal in treated soil in comparison to control soil. The data of physicochemical characteristics and contents of heavy metals in treated soil samples were statistically analyzed (at $95 \%$ confidence level) in terms of analysis of variance (ANOVA) using Statistica 13.0 [30]. The responses having $\mathrm{p}<0.05$ are considered significant.

\section{Results and Discussion}

Despite the addition of various nutrients, soil irrigation by industrial effluent may result in poor growth of plants and increase heavy metal uptake. The results of physicochemical characteristics of soil samples are summarized in Table 1 . Soil $\mathrm{pH}$ determines the nature of soil and administrates the availability of nutrients to the plants. In current study, with the use of effluent compositions, significant decrease in soil $\mathrm{pH}$ was observed. Conversely, $\mathrm{pH}$ of soil treated with $20 \%$ effluent was found statistically different $(p<0.05)$ from those soil samples treated with 80 and 100\% PBM effluent. This reduction in soil $\mathrm{pH}$ may be attributed to the addition of high amount of nutrients and $\mathrm{OM}$ to the soil by wastewater which activates microorganisms to produce organic acids or release of exchangeable cations. The decrease in soil $\mathrm{pH}$ may enhance the soluble and bio-available concentration of nutrients and heavy metals in soil [18, 31]. Increase in EC was found 4-5-fold in soil samples exposed to higher concentration of PBM effluent for 60-90 days. Significant increase in EC was observed after 90 days. This effect may be due to high TDS value of effluent or increase in mineralization of organic contents (high microbial action) as a result of effluent irrigation [32].

Soil organic matter (OM) controls nutrient uptake potential of plants from soil. Effluents with high BOD may increase OM of soil from 22 to $30 \%$. The decrease in soil OM upon irrigation with industrial effluent has been reported. In present study, among different proportions of PBM effluent, only 80 and 100\% of effluent caused significant increase in soil OM after 60 days of treatment. High OM in soil is considered as threat, because OM may act as strong adsorbent for organic and inorganic pollutants that may ultimately be transferred to the plants grown in that particular soil. The $\mathrm{N}$ and $\mathrm{P}$ content are an indicator of soil fertility. In this study, different proportions of PBM effluent individually contributed towards increasing total $\mathrm{N}$ in soil up to significant level $(\mathrm{p}<0.05)$ after 30 days of irrigation. High $\mathrm{N}$ content may lead towards an increase in the bioavailability of heavy metals to the plants.

Significant increase in concentration of available $\mathrm{P}$ was observed after 60 days and 3 to 9 times after 90 days greater than control. Water holding capacity (WHC) of soil was found increasing with continuous 
Table 1. Characteristics of soil after 30,60 and 90 days of irrigation with PBM effluents.

\begin{tabular}{|c|c|c|c|c|c|c|c|c|c|c|c|}
\hline \multicolumn{12}{|c|}{30 days } \\
\hline Effluent Conc. & $\mathrm{pH}$ & $\mathrm{EC}$ & $\mathrm{OM}$ & $\mathrm{N}$ & $\mathrm{P}$ & K & Saturation & Sand & Slit & Clay & Texture \\
\hline$\%$ & & $\mathrm{mS} / \mathrm{cm}$ & \multicolumn{2}{|c|}{$\%$} & \multicolumn{2}{|c|}{ (ppm) } & \multicolumn{4}{|c|}{$\%$} & \\
\hline 0 & 8.2 & 2.61 & 1.34 & 0.0715 & 4.74 & 11.26 & 33 & 41 & 40 & 19 & Loam \\
\hline 20 & 7.8 & 3.17 & 1.39 & 0.148 & 5.418 & 14.38 & 33 & 43 & 40 & 17 & Loam \\
\hline 40 & 7.8 & 8.21 & 1.48 & 0.319 & 8.543 & 15.42 & 35 & 45 & 38 & 17 & Loam \\
\hline 60 & 7.7 & 10.17 & 1.69 & 0.457 & 11.569 & 17.61 & 36 & 46 & 41 & 13 & Loam \\
\hline 80 & 7.6 & 15.94 & 1.88 & 0.663 & 15.417 & 19.53 & 36 & 47 & 42 & 11 & Loam \\
\hline 100 & 7.5 & 18.27 & 2.07 & 0.741 & 19.725 & 20.17 & 37 & 47 & 43 & 10 & Loam \\
\hline \multicolumn{12}{|c|}{60 days } \\
\hline 0 & 8.2 & 2.42 & 1.29 & 0.0645 & 4.65 & 11.82 & 33 & 44 & 38 & 18 & Loam \\
\hline 20 & 7.7 & 4.15 & 1.57 & 0.384 & 6.018 & 15.27 & 34 & 45 & 41 & 15 & Loam \\
\hline 40 & 7.5 & 7.31 & 1.63 & 0.547 & 8.429 & 15.83 & 34 & 47 & 40 & 13 & Loam \\
\hline 60 & 7.3 & 11.52 & 1.71 & 0.772 & 13.51 & 19.77 & 35 & 47 & 43 & 10 & Loam \\
\hline 80 & 7.2 & 17.43 & 2.24 & 0.808 & 20.571 & 22.07 & 37 & 49 & 42 & 9 & Loam \\
\hline 100 & 7.2 & 21.21 & 2.77 & 0.984 & 23.141 & 24.66 & 39 & 48 & 45 & 7 & Loam \\
\hline \multicolumn{12}{|c|}{90 days } \\
\hline 0 & 8.2 & 2.35 & 1.21 & 0.0641 & 3.472 & 11.88 & 34 & 45 & 40 & 15 & Loam \\
\hline 20 & 7.9 & 8.22 & 1.79 & 0.412 & 9.126 & 17.05 & 35 & 45 & 42 & 13 & Loam \\
\hline 40 & 7.7 & 12.9 & 1.93 & 0.648 & 14.517 & 19.14 & 36 & 46 & 42 & 12 & Loam \\
\hline 60 & 7.7 & 16.39 & 2.08 & 0.893 & 17.584 & 22.74 & 38 & 47 & 43 & 10 & Loam \\
\hline 80 & 7.5 & 22.47 & 2.54 & 0.991 & 21.953 & 26.38 & 39 & 49 & 41 & 10 & Loam \\
\hline 100 & 7.4 & 29.13 & 3.01 & 1.127 & 26.817 & 27.94 & 41 & 50 & 44 & 6 & Loam \\
\hline
\end{tabular}

irrigation of PBM effluent and significant change was noted for soil irrigated with 80 and $100 \%$ effluent as compared to control after 60 days. This little change in soil capacity to hold water may be credited to increase in $\mathrm{OM}$ and decrease in clay content in soil. Fractions of sand, silt and clay determine the soil properties including porosity, WHC and water drainage. Amount of sand and silt increased compared to clay content in soil samples exposed to different proportions of PBM effluent. Textural category of soil remained loam at the start and after 90 days of treatment. The levels of heavy metals in soil is one of the major factors which threat the plant growth, as metals possess ability to deactivate biomolecules due to interactions like complex formation or ion-pair associations. The visible symptoms of metal toxicity appear after prolonged exposure to metal contaminated soils $[11,31,33]$. Fig. 1 shows the heavy metal contents in soil irrigated with different PBM effluent compositions at intervals of 30,60 and 90 days. Toxicity of heavy metals in effluent irrigated soil has been presented in literature reports [34-36]. The results for metals in soil indicates that concentration of $\mathrm{Cd}$ remains within the standard limit $\left(1 \mathrm{mg} \mathrm{kg}^{-1}\right)$ even after 90 days of irrigation, if soil is irrigated with $40 \%$ effluent composition.

The Cd level in higher effluent proportions $(60,80$ and $100 \%$ ) were found beyond standard value just after 30 days of irrigation. There was significant increase in Co contents regarding effluent composition and duration of irrigation (Fig. 1). The levels of Co for control soil was $1.43 \mathrm{mg} \mathrm{kg}^{-1}$ which increased after 90 days of irrigation. The increase in Mn content in soil was not found significant as compared to other trace elements. However, after 90 days of irrigation, Mn levels were $0.84,1.28,1.53,2.07$ and $2.43 \mathrm{mg} \mathrm{kg}^{-1}$ in soil treated with $20,40,60,80$ and $100 \%$ effluent respectively. Lower compositions of PBM effluent (20, 40, and 60\%) added significant amount of $\mathrm{Cu}$ in soil which was within standard value $\left(30 \mathrm{mg} \mathrm{kg}^{-1}\right)$ even after 90 days. Higher proportions of PBM (80 and 100\%) raised the amount of $\mathrm{Cu}$ above the standard value after 60 days of irrigation.

Significant increase in the Ni content was observed as compared to control soil $\left(2.06 \mathrm{mg} \mathrm{kg}^{-1}\right)$ and maximum value (71.05 mg kg-1) was calculated for soil treated with pure effluent. Upon addition of $100 \%$ effluent for 90 days the amount of $\mathrm{Ni}$ was $74 \%$. PBM effluent added 

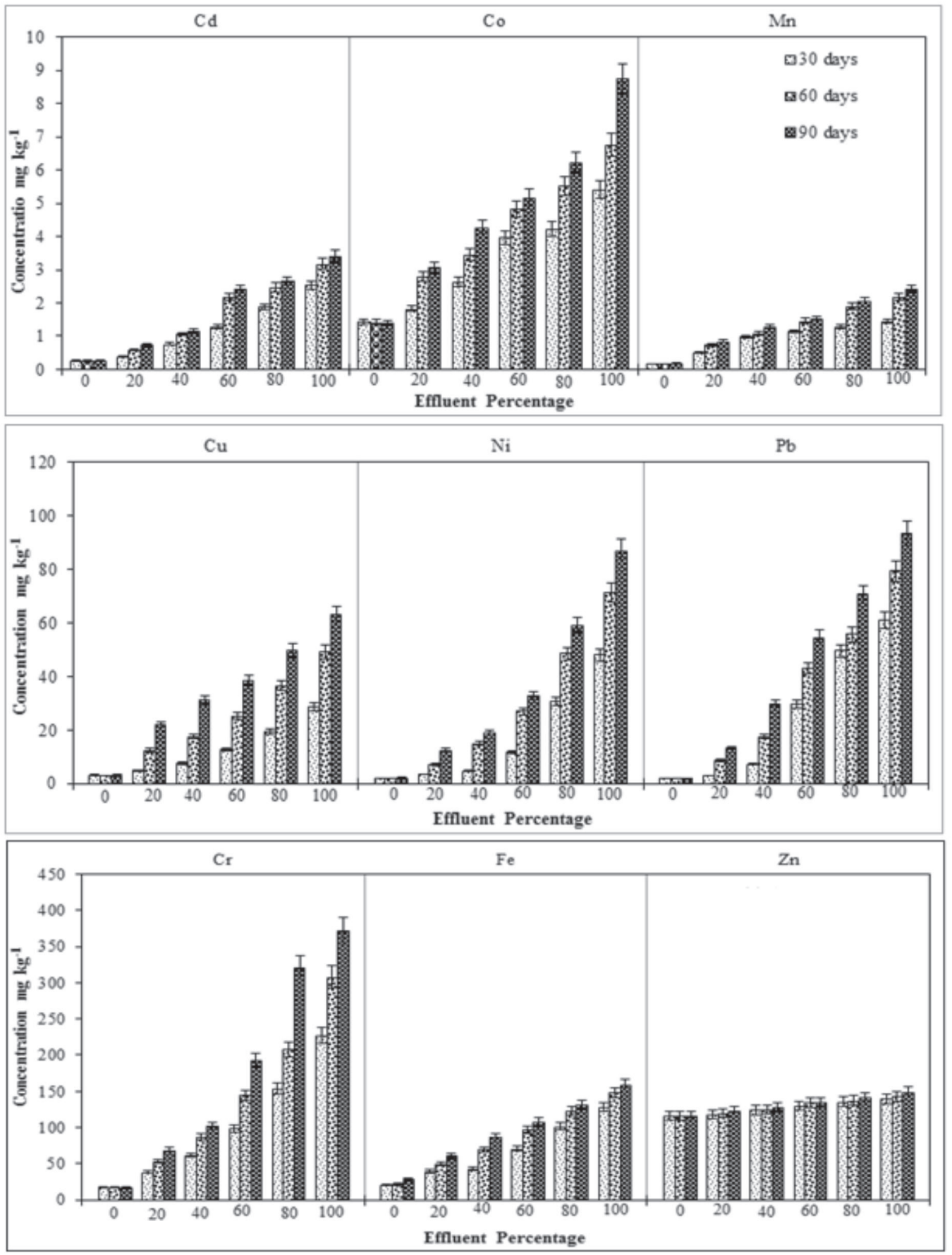

Fig. 1. Effect of different compositions of industrial effluents on metal contnets in soil.

significant amount of $\mathrm{Pb}$ in soil and samples were found having up to $93.43 \mathrm{mg} \mathrm{kg}^{-1} \mathrm{~Pb}$ as compared to control soil (1.72 $\left.\mathrm{mg} \mathrm{kg}^{-1}\right)$. Amongst all the compositions 60, 80 and $100 \%$ effluent concentration introduced $\mathrm{Pb}$ more than standard limit $\left(50 \mathrm{mg} \mathrm{kg}^{-1}\right)$ after 90 days of irrigation.

The amount of $\mathrm{Cr}$ in soil samples treated with 60 , 80 and 100\% PBM effluent for 30 days were huge. However, $\mathrm{Cr}$ content was lower than allowable limit for the soil samples treated with 20 and $40 \%$ effluent even after 90 days. The Fe content for treated soil were 2.5-5.5 folds higher than the control. The distribution of heavy metals in soil irrigated with water after 30 days of effluent irrigation was found in the order $\mathrm{Pb}>\mathrm{Ni}>$ $\mathrm{Cr}>\mathrm{Cu}>\mathrm{Mn}>\mathrm{Cd}>\mathrm{Co}>\mathrm{Fe}>\mathrm{Zn}$ and this trend sustained even after 90 days of irrigation.

\section{Conclusions}

The findings of current study indicate that PBM effluent may cause significant variation in physicochemical properties and proportions of metal contents in soil. Therefore, lower proportions (20 
and $40 \%$ ) of PBM effluent for long term irrigation is recommended as these may add valuable nutrients rather introducing toxic effects. These effluent compositions may improve growth, biochemical contents and yield of plants in the irrigated soil. On the contrary, upon irrigation with higher concentrations of PBM effluent (60, 80 and 100\%) soil may become reservoir of pollutants. In such soil, crops with poor yield and carrying variety of pollutants will be produced that may induce toxicity to consumer and other factions of food chain.

\section{Conflict of Interest}

The authors declare no conflict of interest.

\section{References}

1. ALI K., AKHTAR N., SHUAIB M., ALI S., GHAFFAR A., SHAH M., KHAN A., HUSSAIN F., KHAN Z., KALEEM I., NAZIR A., IQBAL M. Impact of Urbanization on Vegetation: a Survey of Peshawar, Pakistan. Pol. J. Environ. Stud. 28 (4), 2523, 2019.

2. ARIF K., AFZAL Z., NADEEM M., AHMAD B., MAHMOOD A., IQBAL M., NAZIR A. Role of Graph Theory to Facilitate Landscape Connectivity: Subdivision of a Harary Graph. Pol. J. Environ. Stud. 27 (3), 993, 2018.

3. FRASER D.S., O'HALLORAN K., VAN DEN HEUVEL M.R. Toxicity of pulp and paper solid organic waste constituents to soil organisms. Chemosphere 74 (5), 660, 2009.

4. FAHIM S., NISAR N., AHMAD Z., ASGHAR Z., SAID A., ATIF S., GHANI N., QURESHI N., SOOMRO GA., IQBAL M., NAZIR A. Managing Paper and Pulp Industry By-Product Waste Utilizing Sludge as a Bio-Fertilizer. Pol. J. Environ. Stud. 28 (1), 83, 2019.

5. AUSTIN G.T. Shreve's chemical process industries. In: Shreve's chemical process industries. edn.: McGraw-Hill; 1984.

6. IWUOHA G.N., AKINSEYE A. Toxicological symptoms and leachates quality in Elelenwo, Rivers State, Nigeria. Chem. Int. 5 (3), 198, 2019.

7. IQBAL M., ABBAS M., NAZIR A., QAMAR A.Z. Bioassays based on higher plants as excellent dosimeters for ecotoxicity monitoring: A review. Chem. Int. 5 (1), 1, 2019.

8. HASSEN E.B., ASMARE A.M. Predictive performance modeling of Habesha brewery wastewater treatment plant using artificial neural networks. Chem. Int. 5 (1), 87, 2019.

9. ANDREWS D., ROBB T., ELLIOTT H., WATSON J. Impact of long-term wastewater irrigation on the physicochemical properties of humid region soils: "The Living Filter" site case study. Agric. Water Manag. 178, 239, 2016.

10. YOUNAS U., IQBAL S., SALEEM A., IQBAL M., NAZIR A., NOUREEN S., MEHMOOD K., NISAR N. Fertilizer industrial effluents: Physico-chemical characterization and water quality parameters evaluation. Acta Ecol. Sinica. 37 (4), 2369, 2017.
11. SIDDIQUE A., HASSAN A., KHAN SR., INAYAT A., NAZIR A., IQBAL M. Appraisal of heavy metals and nutrients from phosphate rocks, Khyber Pakhtunkhwa, Pakistan. Chem. Int. 4 (1), 1, 2018.

12. IBISI N.E., ASOLUKA C.A. Use of agro-waste (Musa paradisiaca peels) as a sustainable biosorbent for toxic metal ions removal from contaminated water. Chem. Int. 4 (1), 52, 2018.

13. JAFARINEJAD S. Activated sludge combined with powdered activated carbon (PACT process) for the petroleum industry wastewater treatment: A review. Chem. Int. 3 (4), 368, 2017.

14. DJEHAF K., BOUYAKOUB AZ., OUHIB R., BENMANSOUR H., BENTOUAF A., MAHDAD A., MOULAY N., BENSAID D., AMERI M. Textile wastewater in Tlemcen (Western Algeria): Impact, treatment by combined process. Chem. Int. 3 (4), 414, 2017.

15. KHAN F., KHAN M.J., SAMAD A., NOOR Y., RASHID M., JAN B. In-situ stabilization of heavy metals in agriculture soils irrigated with untreated wastewater. J Geochem. Expl. 159, 1, 2015.

16. MAJOLAGBE A.O., ADEYI A.A., OSIBANJO O., ADAMS A.O., OJURI O.O. Pollution vulnerability and health risk assessment of groundwater around an engineering Landfill in Lagos, Nigeria. Chem. Int. 3 (1), $58,2017$.

17. NAZIR A., IFTIKHAR S., ABBAS M., IQBAL M., AHMAD I. Toxicity evaluation of tannery effluents using bioassays. Curr. Sci. Perspect. 5 (3), 29, 2019.

18. MOUHAMAD R., RASHEED A., AL-GBURI H., NAZIR A., IQBAL M., RAZAQ I. Predicting Soil Organic Carbon Turnover in Soils at the Middle Region of Iraqi Using Infrared Spectra. Jacob J. Plant Biol. 4 (1), 1, 2019.

19. IQBAL M., ABBAS M., ADIL M., NAZIR A., AHMAD I. Aflatoxins biosynthesis, toxicity and intervention strategies: A review. Chem. Int. 5 (3), 168, 2019.

20. MOUHMAD R.S., IQBAL M., NAZIR A. A glance at the world. Waste Manag. 76, I-IV, 2018.

21. MOUHAMD R.S., AL LATIF SA., YOUSIR SA., RAZAQ I.B., IQBAL M., ABBAS M., SAJID A., NAZIR A. Impact on hay under salaine conditions of ArbusularMycorrhiza and Bradyrhizobium japonicum. Curr. Sci. Perspect. 3 (2), 97, 2017.

22. MOUHAMAD R.S., MUTLAG L.A., ATIYAH A.H., RAZAQ I.B., ABDULHUSSEIN M.A., IQBAL M., NAZIR A. Salinity tolerance at seedling stage for rice genotypes: In vitro analysis. Net J. Agric. Sci. 5 (4), 126, 2017.

23. MOUHAMAD R.S., MUTLAG L.A., AL-KHATEEB M.T., IQBAL M., NAZIR A., IBRAHIM K.M., MUSSA R.A., JASSAM O.H. Reducing water salinity using effective microorganisms. Net J. Agric. Sci. 5 (3), 114, 2017.

24. MINHAS P., YADAV R. Long-term impact of wastewater irrigation and nutrient rates II. Nutrient balance, nitrate leaching and soil properties under peri-urban cropping systems. Agric. Water Manag. 156, 110, 2015.

25. LIANG Q., GAO R., XI B., ZHANG Y., ZHANG H. Long-term effects of irrigation using water from the river receiving treated industrial wastewater on soil organic carbon fractions and enzyme activities. Agric. Water Manag. 135, 100, 2014.

26. WALKLEY A. A critical examination of a rapid method for determining organic carbon in soils - effect of variations in digestion conditions and of inorganic soil constituents. Soil Sci. 63 (4), 251, 1947. 
27. OLSEN S.R., COLE C., WATANABE F., DEAN L. Estimation of available phosphorus in soil by extraction with sodium bicarbonate US Dept. Agric. Circ. 939, 1954.

28. KLUTE A., DINAUER R.C. Physical and mineralogical methods. Planning 8, 79, 1986.

29. GUPTA S., SATPATI S., NAYEK S., GARAI D. Effect of wastewater irrigation on vegetables in relation to bioaccumulation of heavy metals and biochemical changes. Environ. Monitor. Assess. 165 (1-4), 169, 2010.

30. JABEEN S., ALI S., NADEEM M., ARIF K., QURESHI N., SHAR G.A., SOOMRO G.A., IQBAL M., NAZIR A., SIDDIQUA U.H. Statistical Modeling for the Extraction of Dye from Natural Source and Industrial Applications. Pol. J. Environ. Stud. 28 (4), 2145, 2019.

31. TAHIR M., IQBAL M., ABBAS M., TAHIR M., NAZIR A., IQBAL D.N., KANWAL Q., HASSAN F., YOUNAS U. Comparative study of heavy metals distribution in soil, forage, blood and milk. Acta Ecol. Sinica 37 (3), 207, 2017.

32. PARAMESWARAN V., NALLAMUTHU N., DEVENDRAN P., NAGARAJAN E., MANIKANDAN A. Electrical conductivity studies on Ammonium bromide incorporated with Zwitterionic polymer blend electrolyte for battery application. Phys. B: Cond. Matter. 515, 89, 2017.

33. ARSHAD M., QAYYUM A., ABBAS G., HAIDER R., IQBAL M., NAZIR A. Influence of different solvents on portrayal and photocatalytic activity of tin-doped zinc oxide nanoparticles. J. Mol. Liq. 260, 272, 2018.

34. CHIKWE T.N., EKPO R.E., OKOYE I. Competitive adsorption of organic solvents using modified and unmodified calcium bentonite clay mineral. Chem. Int. 4(4), 230-239, 2018.

35. 35. LEGROURI K, KHOUYA E, HANNACHE H, EL HARTTI M, EZZINE M, NASLAIN R. Activated carbon from molasses efficiency for $\mathrm{Cr}$ (VI), $\mathrm{Pb}$ (II) and $\mathrm{Cu}$ (II) adsorption: a mechanistic study. Chem. Int. 3 (3), 301, 2017.

36. ELVIA R., CAHYANA A.H., WIBOWO W. Catalytic acetylation of $(+)$-cedrol with heterogeneous catalyst $\mathrm{H}_{2} \mathrm{SO}_{4} / \mathrm{SiO}_{2}$ under solvent free conditions. Chem. Int. 1 (4), 196, 2015 . 